\title{
Synthesis, vibrational characterization and antioxidant activity of newly synthesized indium(III) complex
}

\author{
Kostova $\mathbf{I}^{*}$, Atanasova $\mathrm{V}^{1}$, Todorov $\mathrm{L}^{1}$, Kondeva-Burdina $\mathrm{M}^{2}$ and Tzankova $\mathrm{V}^{2}$ \\ ${ }^{1}$ Department of Chemistry, Faculty of Pharmacy, Medical University, Dunav St., Sofia 1000, Bulgaria \\ ${ }^{2}$ Department of Pharmacology, Pharmacotherapy and Toxicology, Faculty of Pharmacy, Medical University, 2 Dunav St, Sofia 1000, Bulgaria
}

\begin{abstract}
The synthesis of indium(III) complex of orotic acid (HOA) was described and the composition and the structure of In(III) complex ware determined by means of analytical and spectral analyses. Detailed vibrational analysis of HOA, sodium salt of HOA (NaOA) and In(III)-OA systems based on both the calculated and experimental spectra confirmed the suggested metal-ligand binding mode. The calculated vibrational wavenumbers including IR and Raman scattering activities for the ligand and its In(III) complex were in good agreement with the experimental data. The vibrational analysis performed for the studied species, orotic acid, sodium salt of orotic acid and its In(III) complex, helped to explain the vibrational behaviour of the ligand vibrational modes, sensitive to interaction with In(III). The compounds HOA, NaOA and InOA were investigated for possible antioxidant activity in a model of non-enzyme-induced lipid peroxidation on isolated rat microsomes. On isolated rat microsomes, administered alone, the compounds didn't revealed pro-oxidant effects. In conditions of non-enzyme-induced lipid peroxidation, only the complex InOA showed antioxidant activity. HOA and $\mathrm{NaOA}$ didn't reveal antioxidant activity. We suggest that the antioxidant activity of the complex InOA, might be due to the presence of indium(III) in the structure of InOA.
\end{abstract}

\section{Introduction}

Coordination compounds of orotic acid and its substituted derivatives continue to attract attention because of the multidentate functionality of theligand and its role in bioinorganic and pharmaceutical chemistry [1-5]. Orotic acid (2,6-dioxo-1,2,3,6-tetrahydropyrimidine4-carboxylic acid, HOA) (Figure 1) is a natural substance classified more than 40 years ago as vitamin B13 and mainly used in the past for the treatment of pernicious anaemia. Its major metabolic role within the human body consists of that it is the first fully formed intermediate in the manufacture of the pyrimidine bases required for the RNA/DNA synthesis. Metal orotates are also widely applied in medicine [6,7].

The structure of sodium salt of orotic acid $\mathrm{NaOA}$ is presented in (Figure 2). Orotic acid acts as a diacid in aqueous solution [8,9]. The coordinated orotate anions exhibit a ligand surface with double or triple hydrogen-bonding capabilities, depending on the metal coordination mode, and have thus a potential to adopt several modes of interligand hydrogen bonding. Orotic acid has demonstrated versatile coordination modes during the formation of coordination frameworks, that is why it was a challenge for us to obtain new metal coordination complexes with orotic acid, especially in view of their application as anticancer and antioxidant agents. We have recently synthesized lanthanide(III) complexes with a number of biologically active ligands, and we reported their significant antioxidant and cytotoxic activity in different human cell lines [10-16]. These promising results prompted us to search for new metal complexes with orotic acid. Thus, the aim of this work was to synthesize and characterize a complex of indium(III) with orotic acid in view of determination of its antioxidant activity.

Group IIIa metals especially gallium and indium are of major current interest as components of medicinal inorganic therapeutic and diagnostic agents. It has been shown that not only gallium, but also indium and in some cases aluminum salts prevent the growth

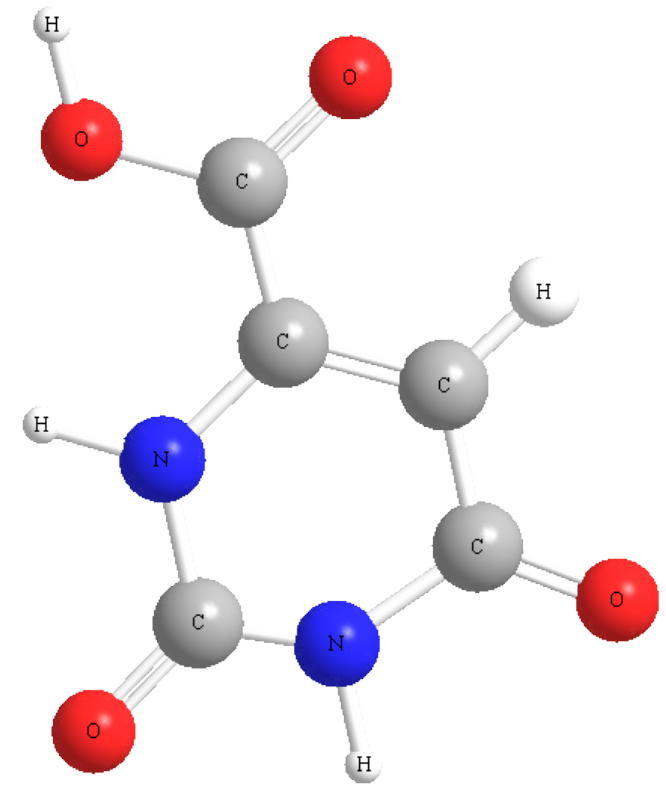

Figure 1. The structure of the ligand orotic acid

*Correspondence to: Irena Kostova, DSc, Department of Chemistry, Faculty of Pharmacy, Medical University, 2 Dunav St., Sofia 1000, Bulgaria, Tel: +359 292 36 569, E-mail: irenakostova@yahoo.com

Key words: In(III) complex, orotic acid, FT-Raman, FT-IR, antioxidant activity Received: July 19, 2018; Accepted: July 25, 2018; Published: August 13, 2018 


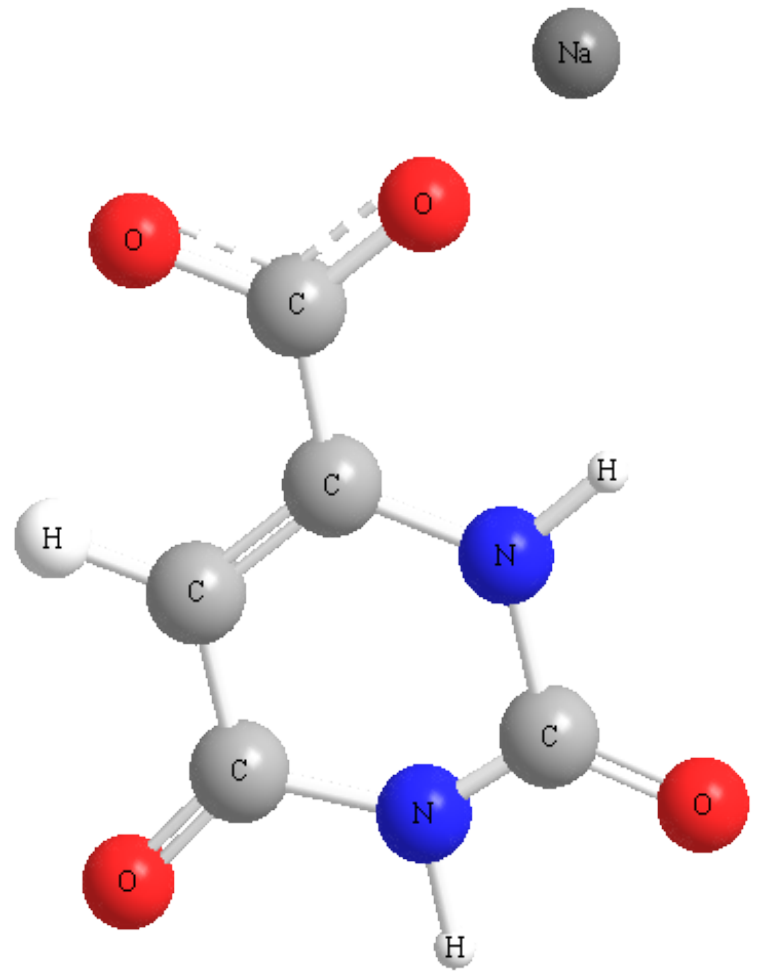

Figure 2. The structure of sodium salt of orotic acid

of various experimental solid tumors $[17,18]$. Gallium is the second metal ion, after platinum, to be used in cancer treatment. Its activities are numerous and various. It modifies three-dimensional structure of DNA and inhibit's its synthesis, modulates protein synthesis, inhibit's the activity of a number of enzymes, such as ATPases, DNA polymerases, ribonucleotide reductase and tyrosine-specific protein phosphatase. Gallium alters plasma membrane permeability and mitochondrial functions $[17,18]$. It has been revealed that indium curcumin complex, diacetylcurcumin, and indium diacetylcurcumin have anticancer activity. New $\mathrm{Ga}$ (III) and In(III) compounds with a better bioavailability are now under clinical investigations and could improve the anticancer and antioxidant activity first demonstrated with their inorganic salts [18].

In this paper we report analytical and spectroscopic results about the new In(III) complex of orotic acid (HOA). The In(III)-OA binding mode was identified and characterized by elemental analysis, IR and Raman spectroscopies. For estimation of the most preferred reactive sites of HOA for electrophilic attack and metal binding, DFT calculations of the vibrational structure of HOA have been performed. The compounds $\mathrm{HOA}, \mathrm{NaOA}$ and InOA have been investigated for possible antioxidant activity in a model of non-enzyme-induced lipid peroxidation on isolated rat liver microsomes, model of lipid membrane.

\section{Materials and Methods}

\section{Chemistry}

Synthesis of the coordination complex: The compounds used for preparing the solutions were Sigma-Aldrich products, p.a. grade: $\mathrm{In}\left(\mathrm{NO}_{3}\right)_{3}$. The sodium salt of orotic acid was used for the preparation of the metal complex as a ligand. The complex was synthesized by reaction of indium(III) nitrate and the sodium salt of orotic acid in aqueous solution, in amounts equal to metal: ligand molar ratio of 1: 3 . The complex was prepared by adding an aqueous solution of indium(III) salt to an aqueous solution of the sodium salt of orotic acid. The reaction mixture was stirred with an electromagnetic stirrer at 25 $\mathrm{oC}$ for one hour. At the moment of mixing of the solutions, precipitate was obtained. The precipitate was filtered ( $\mathrm{pH}$ of the filtrate was 5.0), washed several times with water and dried in a desiccator to constant weight.

The complex was insoluble in water, methanol and ethanol and well soluble in DMSO.

Chemistry device descriptions: The carbon, hydrogen and nitrogen contents of the compound were determined by elemental analysis. The water content was determined by thermogravimetrical analysis.

The solid-state infrared spectra of the ligand and its In (III) complex were recorded in $\mathrm{KBr}$ in the $4000-400 \mathrm{~cm}^{-1}$ frequency range by FT-IR $113 \mathrm{~V}$ Bruker spectrometer.

The Raman spectra of orotic acid and its new In(III) complex were recorded with a Dilor Labram spectrometer (Horiba-Jobin-Yvon, model LabRam) using the $784.8 \mathrm{~nm}$ excitation line from a near infrared Diode laser. The Labram integrated system is coupled trough an Olympus LMPlanFL 50x objective to the optical microscope. The spectra were collected in the backscattering geometry with a resolution of $2 \mathrm{~cm}^{-1}$. The detection of Raman signal was carried out with a Peltier-cooled CCD camera. The laser power of $35 \mathrm{~mW}$ was used in our measurements.

Computational details: The geometry of orotic acid was optimized using the Gaussian 03 program [19]. Becke's three-parameter exchange functional (B3) [20] with Perdew and Wang's gradient-corrected correlation functional (PW91) [21,22] and Becke's three-parameter hybrid exchange functional (B3) $[23,24]$ using the LYP correlational functional of Lee, Yang and Parr (LYP) [25,26] were employed in the DFT calculations. The 6-311++ $\mathrm{G}^{* *}$ Pople split valence basis sets along with the LANL2DZ basis set implemented in the Gaussian 03 program 19 were chosen in the geometry optimization and normal modes calculations.

Using the fully optimized molecular geometry we performed the density functional theory (DFT) calculations on harmonic vibrational modes for the ligand. Harmonic vibrational wavenumbers including IR and Raman intensities were calculated analytically for the fully optimized molecular geometry of the ligand. Only real harmonic vibrational wavenumbers were obtained for all structures, confirming the localization of global minima on the potential energy surfaces.

\section{Pharmacology}

In our experiments, $\mathrm{KH}_{2} \mathrm{PO}_{4}, \mathrm{~K}_{2} \mathrm{HPO}_{4}, \mathrm{KCl}$, (Scharlau Chemie SA, Spain), 2-thiobarbituric acid (4,6-dihydroxypyrimidine-2-thiol; TBA), Fenol reagent, $\mathrm{FeSO}_{4}$, Ascorbinic acid (Sigma Aldrich), trichloroacetic acid (TCA) and Glycerol (Valerus, Bulgaria) were used.

Animals: Male Wistar rats (body weight 200-250 g) were used. The rats were housed in plexiglass cages (3 per cage) in a 12/12 light/dark cycle, under standard laboratory conditions (ambient temperature 20 $\pm 2{ }^{\circ} \mathrm{C}$ and humidity $72 \pm 4 \%$ ) with free access to water and standard pelleted rat food 53-3, produced according to ISO 9001:2008.

Animals were purchased from the National Breeding Centre, Sofia, Bulgaria. At least 7 days of acclimatization was allowed before the commencement of the study. The health was monitored regularly by a veterinary physician. The vivarium (certificate of registration of farm 
№ 0072/01.08.2007) was inspected by the Bulgarian Drug Agency in order to check the husbandry conditions (№ A-11-1081/03.11.2011). All performed procedures were approved by the Institutional Animal Care Committee and made according Ordinance № 15/2006 for humaneness behaviour to experimental animals. The principles stated in the European Convention for the Protection of Vertebrate Animals used for Experiments and other Scientific Purposes (ETS 123) (Council of Europe, 1991) were strictly followed throughout the experiment.

Isolation of liver microsomes: Liver is perfused with $1.15 \% \mathrm{KCl}$ and homogenized with four volumes of ice-cold $0.1 \mathrm{M}$ potassium phosphate buffer, $\mathrm{pH}=7,4$. The liver homogenate was centrifuged at $9000 \mathrm{x} \mathrm{g}$ for $30 \mathrm{~min}$ at $4^{\circ} \mathrm{C}$ and the resulting post-mitochondrial fraction (S9) was centrifuged again at $105000 \mathrm{xg}$ for $60 \mathrm{~min}$ at $4^{\circ} \mathrm{C}$. The microsomal pellets were re-suspended in $0.1 \mathrm{M}$ potassium phosphate buffer, $\mathrm{pH}=7.4$, containing $20 \%$ Glycerol. Aliquots of liver microsomes were stored at $-70^{\circ} \mathrm{C}$ until use [27].

The content of microsomal protein was determined according to the method of Lowry using bovine serum albumin as a standard [28].

$\mathrm{FeSO}_{4} /$ Ascorbic acid-induced lipid peroxidation in vitro: As a system, in which metabolic activation may not be required in the production of lipid peroxide, $20 \mu \mathrm{M} \mathrm{FeSO}_{4}$ and $500 \mu \mathrm{M}$ Ascorbic acid were added directly into rat liver microsomes and incubated for $20 \mathrm{~min}$ at $37^{\circ} \mathrm{C}[29]$.

Microsomes' incubation with $\mathrm{HOA}, \mathrm{NaOA}$ and InOA: Liver microsomes were incubated with concentration $100 \mu \mathrm{M}$ of the investigated compounds [30].

Lipid peroxidation in microsomes: After incubation of microsomes $(1 \mathrm{mg} / \mathrm{ml}$ ) with the compounds, we added to the microsomes $1 \mathrm{ml} 25 \%$ (w/v) trichloroacetic acid (TCA) and $1 \mathrm{ml} 0.67 \%$ 2-Thiobarbituric acid (TBA). The mixture was heated at $100{ }^{\circ} \mathrm{C}$ for $20 \mathrm{~min}$. The absorbance was measured at $535 \mathrm{~nm}$, and the amount of MDA was calculated using a molar extinction coefficient of $1.56 \times 10^{5} \mathrm{M}^{-1} \mathrm{~cm}^{-1}$ [29].

Statistical analysis: Statistical analysis was performed using statistical programme 'MEDCALC'. Results are expressed as mean \pm SEM for 5 experiments. The significance of the data was assessed using the nonparametric Mann-Whitney test. A level of $\mathrm{P}<0.05$ was considered significant. Three parallel samples were used.

\section{Results and Discussion}

\section{Chemistry}

The new complex was characterized by elemental analysis. The content of the metal ion was determined after mineralization. The water content in the complex was determined thermogravimetrically. IR and Raman spectra confirmed the nature of the complex.

The data of the elemental analysis of the new indium(III) complex obtained serving as a basis for the determination of its empirical formula are presented below.

Elemental analysis of In(III) complex of orotic acid: (\% calculated/ found): $\mathrm{In}(\mathrm{OA}) 3.4 \mathrm{H} 2 \mathrm{O}$ : C: 25.57/25.47; $\mathrm{H}: 2.41 / 2.24$; N: 11.93/11.79; H2O: $10.23 / 10.25$; In: 23.72/24.06, where $\mathrm{HOA}=\mathrm{C}_{5} \mathrm{~N}_{2} \mathrm{O}_{4} \mathrm{H}_{4}$ and $\mathrm{OA}^{-}=$ $\mathrm{C}_{5} \mathrm{~N}_{2} \mathrm{O}_{4} \mathrm{H}_{3}$.

The mode of bonding of the ligand to In(III) ions was elucidated by recording the IR and Raman spectra of the complex as compared with those of the free ligand and the theoretical predictions. The vibrational fundamentals from the IR and Raman spectra were analysed by comparing these modes with those from the literature [31-35] in combination with the results of our DFT calculations (i.e., harmonic vibrational wavenumbers and their Raman scattering activities) for the ligand [34] and for the In(III) complex.

\section{Vibrational spectroscopy}

In (Table 1) the selected calculated and experimental IR and Raman data together with their tentative assignments are given. The vibrational IR and Raman spectra of HOA, sodium salt of orotic acid $\mathrm{NaOA}$ and In(III)-OA are presented in (Figures 3) and (Figures 4). Significant differences in the IR and Raman spectra of the complex were observed as compared to the spectra of the ligand and confirmed the suggested metal-ligand binding mode. The vibrational fundamentals from the IR and Raman spectra were analysed by comparing these modes with

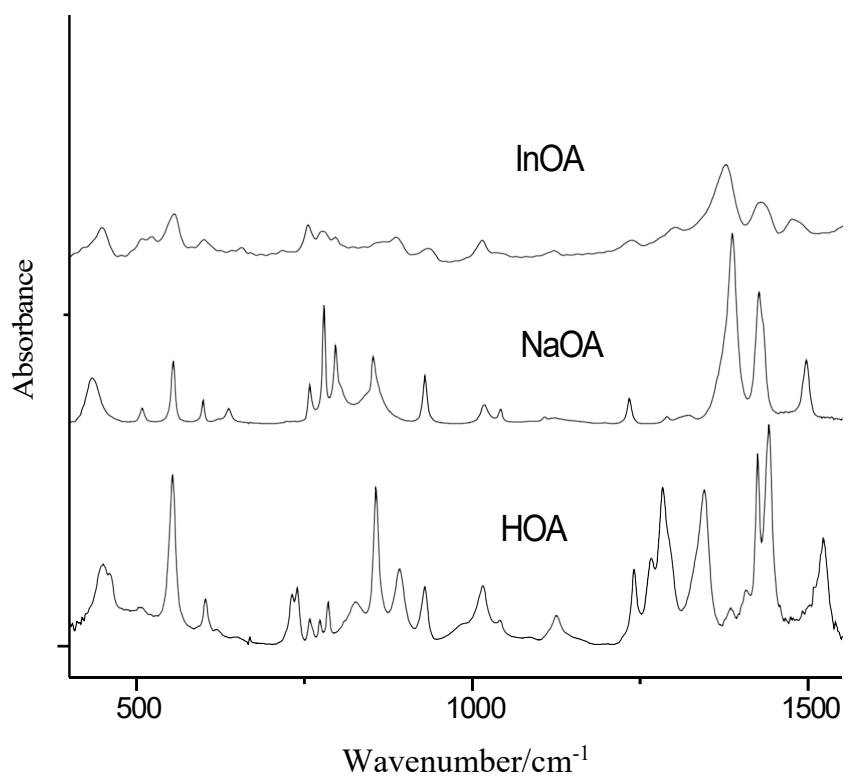

Figure 3. IR spectra of orotic acid (HOA), sodium salt of orotic acid (NaOA) and its In(III) complex $\left(400-2000 \mathrm{~cm}^{-1}\right)$

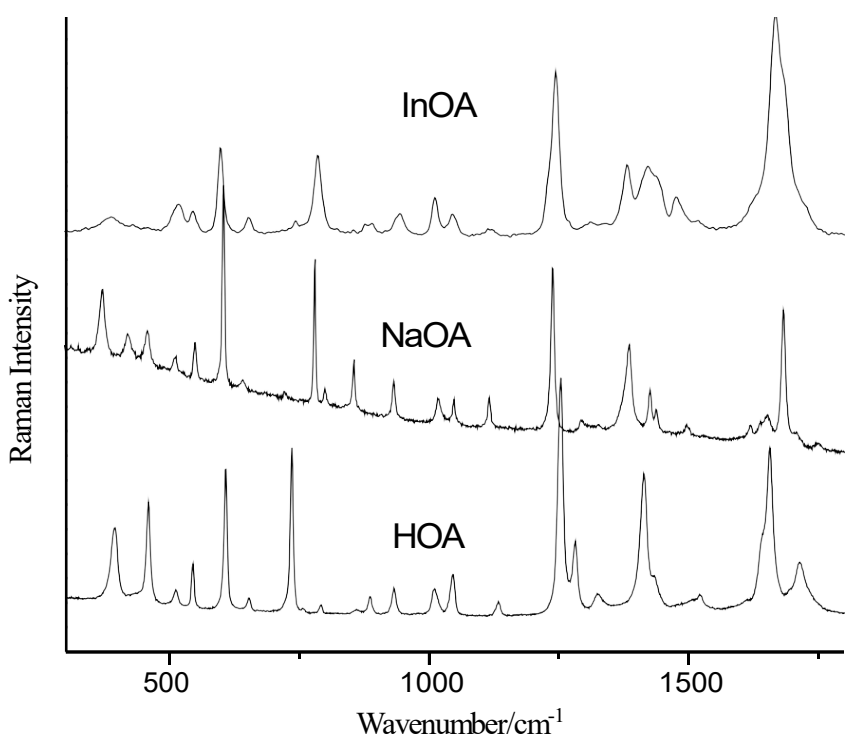

Figure 4. Raman spectra of the solid state of orotic acid (HOA), sodium salt of orotic acid (NaOA) and its In(III) complex. Excitation: $784.8 \mathrm{~nm}, 35 \mathrm{~mW}$ 
Table 1. Selected theoretical and experimental IR and Raman wavenumbers $\left(\mathrm{cm}^{-1}\right)$ of orotic acid (HOA) and its In(III) complex (InOA) and their tentative assignment

\begin{tabular}{|c|c|c|c|c|c|}
\hline \multirow{3}{*}{$\begin{array}{c}\begin{array}{c}\text { Frequency } \\
\text { scaled }\end{array} \\
253 \\
\end{array}$} & \multirow{2}{*}{\multicolumn{2}{|c|}{$\begin{array}{c}\text { Experimental Raman } \\
\text { HOA InOA }\end{array}$}} & \multicolumn{2}{|c|}{ Experimental IR } & \multirow{2}{*}{ Assignments } \\
\hline & & & & & \\
\hline & & 306 & & & $v(\mathrm{O} 1-\mathrm{In})$ \\
\hline 269 & & & & & $v\left(\mathrm{O} 1^{\prime}-\mathrm{In}\right), v\left(\mathrm{O} 3^{\prime}-\mathrm{In}\right)$ \\
\hline 337 & & 345 & & & $v(\mathrm{C} 6-\mathrm{C} 7)$ \\
\hline 380 & 395 & 383 & & & 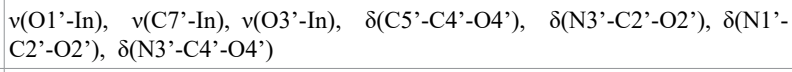 \\
\hline 409 & & & & & $\delta(\mathrm{C} 5-\mathrm{C} 4-\mathrm{O} 4), \gamma(\mathrm{O} 5-\mathrm{H} 6), \delta(\mathrm{C} 2-\mathrm{N} 3-\mathrm{C} 4), \delta(\mathrm{N} 1-\mathrm{C} 2-\mathrm{O} 2)$ \\
\hline 434 & & 440 & & 473 & $v\left(\mathrm{O} 1^{\prime}-\mathrm{In}\right), v\left(\mathrm{O} 3^{\prime}-\mathrm{In}\right), v\left(\mathrm{C} 7^{\prime}-\mathrm{In}\right)$ \\
\hline 464 & 460 & 470 & 451 & & $\delta(\mathrm{C} 6-\mathrm{C} 7-\mathrm{O} 1), v(\mathrm{O} 1-\mathrm{In}), \delta(\mathrm{C} 7-\mathrm{O} 1-\mathrm{In}), \delta(\mathrm{N} 1-\mathrm{C} 2-\mathrm{O} 2)$ \\
\hline 480 & & & & & $\gamma(\mathrm{O} 5-\mathrm{H} 6), \gamma(\mathrm{H1}-\mathrm{O} 5)$ \\
\hline 506 & 513 & 520 & 507 & 517 & $\gamma(\mathrm{C} 7-\mathrm{O} 1), \gamma(\mathrm{N} 1-\mathrm{C} 6), \gamma(\mathrm{C} 6-\mathrm{C} 7)$ \\
\hline 510 & & & & & $\gamma\left(\mathrm{C}^{\prime}-\mathrm{C} 77^{\prime}\right), \delta\left(\mathrm{N}^{\prime}{ }^{\prime}-\mathrm{C} 6{ }^{\prime}-\mathrm{C} 5^{\prime}\right)$ \\
\hline 529 & & & & & 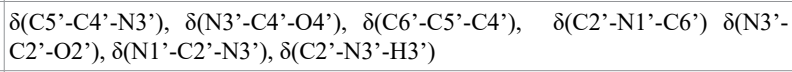 \\
\hline 533 & 546 & 553 & 555 & 538 & $\gamma(\mathrm{HI}-\mathrm{O} 5), \delta(\mathrm{N} 3-\mathrm{C} 4-\mathrm{O} 4), \delta(\mathrm{C} 6-\mathrm{C} 5-\mathrm{C} 4), \delta(\mathrm{C} 5-\mathrm{C} 4-\mathrm{N} 3), \delta(\mathrm{C} 2-\mathrm{N} 1-\mathrm{C} 6)$ \\
\hline 579 & & & & & $\delta(\mathrm{C} 2-\mathrm{N} 3-\mathrm{C} 4), \gamma(\mathrm{C} 4-\mathrm{N} 3), \delta(\mathrm{N} 1-\mathrm{C} 2-\mathrm{N} 3)$ \\
\hline 582 & & & & & $\delta\left(\mathrm{C}^{\prime}{ }^{\prime}-\mathrm{N} 3^{\prime}-\mathrm{C} 4^{\prime}\right), \gamma\left(\mathrm{C} 4^{\prime}-\mathrm{N} 3^{\prime}\right)$ \\
\hline 596 & 608 & 602 & 603 & 595 & $v(\operatorname{In}-\mathrm{O} 5)$ \\
\hline 615 & & & & & $\gamma\left(\mathrm{N} 1{ }^{\prime}-\mathrm{H} 1{ }^{\prime}\right)$ \\
\hline 659 & & & & & $\delta(\mathrm{N} 3-\mathrm{C} 2-\mathrm{N} 1), \gamma(\mathrm{N} 3-\mathrm{H} 3), \gamma(\mathrm{H} 1-\mathrm{N} 1)$ \\
\hline 691 & 653 & 646 & & 633 & $\gamma\left(\mathrm{N}^{\prime}{ }^{\prime}-\mathrm{H} 3{ }^{\prime}\right), \gamma\left(\mathrm{N} 1{ }^{\prime}-\mathrm{H} 1{ }^{\prime}\right)$ \\
\hline 696 & & & & & $\gamma(\mathrm{N} 3-\mathrm{H} 3), \delta(\mathrm{N} 1-\mathrm{C} 2-\mathrm{N} 2), \gamma(\mathrm{N} 1-\mathrm{H} 1)$ \\
\hline 758 & & & & & $\gamma(\mathrm{O} 2-\mathrm{C} 2), \gamma(\mathrm{H} 5-\mathrm{C} 5)$ \\
\hline 765 & 753 & 744 & 758 & & $\gamma\left(\mathrm{C} 2^{\prime} \mathrm{O}\right), \gamma\left(\mathrm{C} 2^{\prime} \mathrm{N}\right)$ \\
\hline 769 & & & & & $\gamma(\mathrm{C} 2-\mathrm{O} 2), \gamma(\mathrm{C} 2 \mathrm{~N})$ \\
\hline 782 & & & & & $\delta\left({\mathrm{C} 7 \mathrm{O}_{2}}_{2}\right), v(\mathrm{O} 1-\mathrm{In})$ \\
\hline 795 & 792 & 786 & 786 & 743 & $\delta\left(\mathrm{C}^{\prime} \mathrm{O}_{2}\right), v\left(\mathrm{C} 7^{\prime}-\mathrm{In}\right)$ \\
\hline 800 & & & & & $\gamma(\mathrm{O} 1-\mathrm{In}), \mathrm{w}\left(\mathrm{CO}_{2}\right), \gamma(\mathrm{C}-\mathrm{H}, \mathrm{N}-\mathrm{H})$ \\
\hline 810 & & & & & $\mathrm{w}\left(\mathrm{CO}_{2}\right), \gamma(\mathrm{C}-\mathrm{H})$ \\
\hline 885 & 887 & 893 & 892 & & 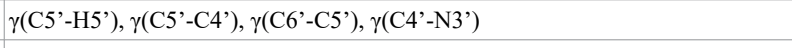 \\
\hline 891 & & & & & $\gamma(\mathrm{C} 5-\mathrm{H} 5)$ \\
\hline 930 & 933 & 949 & 930 & 911 & $v\left(\mathrm{C} 6^{\prime}-\mathrm{C} 7^{\prime}\right)$ \\
\hline 931 & & & & & $v(\mathrm{C} 6-\mathrm{C} 7), \delta(\mathrm{C} 2-\mathrm{N} 3-\mathrm{C} 4)$ \\
\hline 973 & 1011 & 1016 & 1015 & 1027 & $\delta(\mathrm{C} 2-\mathrm{N} 3-\mathrm{H} 3), \delta(\mathrm{C} 2-\mathrm{N} 3-\mathrm{H} 3), \delta(\mathrm{C} 6-\mathrm{C} 5-\mathrm{H} 5), \delta(\mathrm{C} 2-\mathrm{N} 1-\mathrm{C} 6)$ \\
\hline 992 & 1047 & 1047 & 1042 & & $\delta\left(\mathrm{C}^{\prime}-\mathrm{C} 5^{\prime}-\mathrm{C} 4^{\prime}\right), \delta\left(\mathrm{N}^{\prime}-\mathrm{C} 6^{\prime}-\mathrm{C} 5^{\prime}\right), v\left(\mathrm{C} 6^{\prime}-\mathrm{C} 7^{\prime}\right), \delta\left(\mathrm{C}^{\prime}-\mathrm{N}^{\prime}-\mathrm{C} 6^{\prime}\right)$ \\
\hline 1071 & & 1114 & & & $\delta\left(\mathrm{C}^{\prime}-\mathrm{C} 5{ }^{\prime}-\mathrm{H} 5^{\prime}\right), \delta\left(\mathrm{C}^{\prime}-\mathrm{C} 5^{\prime}-\mathrm{H} 5^{\prime}\right)$ \\
\hline 1075 & 1134 & 1145 & 1125 & 1137 & $\delta(\mathrm{C} 6-\mathrm{C} 5-\mathrm{H} 5), \delta(\mathrm{C} 4-\mathrm{C} 5-\mathrm{H} 5)$ \\
\hline 1165 & & 1205 & & & $v(\mathrm{C} 4-\mathrm{N} 3)$ \\
\hline 1169 & 1254 & 1241 & 1241 & & $v\left(\mathrm{C}^{\prime}{ }^{\prime}-\mathrm{N} 3^{\prime}\right)$ \\
\hline 1247 & 1282 & 1300 & 1284 & 1258 & $\delta\left(\mathrm{N} 11^{\prime}-\mathrm{H} 1{ }^{\prime}\right), \delta\left(\mathrm{C} 5^{\prime}-\mathrm{H} 5{ }^{\prime}\right)$ \\
\hline 1281 & 1326 & 1319 & 1345 & 1320 & $\delta(\mathrm{N} 1-\mathrm{H} 1), \delta(\mathrm{C} 5-\mathrm{H} 5)$ \\
\hline 1383 & 1414 & 1380 & 1407 & 1401 & $v_{s}\left(\mathrm{C}^{\prime}{ }^{\prime} \mathrm{O}_{2}\right), v\left(\mathrm{C} 6^{\prime}-\mathrm{C} 7^{\prime}\right)$ \\
\hline 1464 & 1522 & 1479 & 1522 & 1460 & $v\left(\mathrm{~N}^{\prime}{ }^{\prime}-\mathrm{C} 6^{\prime}\right), \quad v\left(\mathrm{C} 7^{\prime}-\mathrm{O} 3^{\prime}\right), v\left(\mathrm{C} 6^{\prime}-\mathrm{C} 7^{\prime}\right)$ \\
\hline 1512 & & & & & $v_{\mathrm{as}}\left(\mathrm{C}^{\prime}-\mathrm{O}_{2}\right)$ \\
\hline 1612 & 1615 & 1622 & 1617 & 1631 & $v(\mathrm{C} 6-\mathrm{C} 5)$ \\
\hline 1623 & & & & & $v\left(\mathrm{C}^{\prime}-\mathrm{C} 5^{\prime}\right)$ \\
\hline 1721 & 1657 & 1671 & 1684 & 1698 & $v(\mathrm{C} 4-\mathrm{O} 4)$ \\
\hline 1725 & & & & & $v\left(\mathrm{C}^{\prime}{ }^{\prime}-\mathrm{O} 4{ }^{\prime}\right)$ \\
\hline 1727 & & 1748 & & & $v(\mathrm{C} 7-\mathrm{O} 3)$ \\
\hline 1736 & 1715 & 1714 & 1712 & & $v(\mathrm{C} 2-\mathrm{O} 2)$ \\
\hline 1766 & & & & & $v\left(\mathrm{C} 2{ }^{\prime}-\mathrm{O} 2{ }^{\prime}\right)$ \\
\hline 3138 & & & & & $v\left(\mathrm{C}^{\prime}-\mathrm{H} 5^{\prime}\right)$ \\
\hline 3354 & & & 3520 & 3437 & $v(\mathrm{~N} 1-\mathrm{H} 1), v(\mathrm{H} 1-\mathrm{O} 5)$ \\
\hline 3642 & 3144 & & 3232 & 3199 & $v(\mathrm{O} 5-\mathrm{H} 6)$ \\
\hline
\end{tabular}


those from the literature 34 in combination with the results of our DFT calculations (i.e., harmonic vibrational wavenumbers and their Raman scattering activities).

In the $3600-2000 \mathrm{~cm}^{-1}$ spectral region from the IR spectrum the $\mathrm{O}-\mathrm{H}$ and $\mathrm{N}-\mathrm{H}$ stretches give rise to medium IR bands (Figure 3). The $\mathrm{O}-\mathrm{H}$ and $\mathrm{N}-\mathrm{H}$ bands appear overlapped in the same spectral region, and the involvement of these groups in hydrogen bonds affects their wavenumbers and produces a relevant band broadening [32-35]. In the IR spectrum of orotic acid the medium band at $3520 \mathrm{~cm}^{-1}$ was assigned to the $\mathrm{N}-\mathrm{H}$ stretching modes, while the shoulder at $3232 \mathrm{~cm}^{-1}$ was attributed to the $\mathrm{O}-\mathrm{H}$ stretching modes (Table 1). The wavenumber region $2700-2500 \mathrm{~cm}^{-1}$ in the IR spectra of orotic acid and its complex is typical of strongly hydrogen bonded intermolecular complexes with overtones and combinations of lower frequency modes of the bonded molecules [36-43].

When the carbonyl is hydrogen bonded but not dimerized, a bond active in both IR and Raman spectra appears at 1730-1705 $\mathrm{cm}^{-1}$. In our IR spectra, one very strong band can be observed in this region (at $1712 \mathrm{~cm}^{-1}$ for orotic acid), which was assigned to the symmetrical stretching mode of $\mathrm{C} 2=\mathrm{O} 2$ and to the $\mathrm{N}-\mathrm{H}$ stretching mode. In this region were observed one medium band at $1715 \mathrm{~cm}^{-1}$ in the Raman spectrum of the free ligand, and two shoulders in the Raman spectrum of the complex (Figure 3) [36-40]. The very strong bands at $1684 \mathrm{~cm}^{-1}$ were assigned to the symmetrical stretching modes of $\mathrm{C} 4=\mathrm{O} 4$ and to the $\mathrm{C} 6=\mathrm{C} 5$ stretching modes. In the Raman spectra, these vibrations can be observed as very strong bands at 1657 and $1671 \mathrm{~cm}^{-1}$ for orotic acid and its In(III) complex, respectively.

The asymmetrical COO- stretching mode was observed as a medium band at $1522 \mathrm{~cm}^{-1}$ (in the IR spectrum of orotic acid) and as a shifted shoulder (in the IR spectra of the complex). The symmetrical COO- stretching mode was observed in the IR spectra at 1407 and 1401 $\mathrm{cm}^{-1}$ for the ligand and its In(III) complex, respectively, while in the Raman spectra this vibration appears as a strong peak at $1414 \mathrm{~cm}^{-1}$ for the free ligand and as a medium band for the complex at $1380 \mathrm{~cm}^{-1}$ (Figure 4). In the $1800-900 \mathrm{~cm}^{-1}$ spectral region of the IR spectra, the bands at 1345 and $1320 \mathrm{~cm}^{-1}$ for the free ligand and its complex (Figure 3 ) can be due to the stretching modes of N-H. These vibrations are rather different and shifted in the Raman spectra for the free ligand and for the complex.

The C5-H5, N1-H1, and C-O-H bending modes are present in the IR spectra as well as in the Raman spectra. In the IR spectra they are observed at $1284 \mathrm{~cm}^{-1}$ for the free ligand, while in the Raman spectra they are detected at $1282 \mathrm{~cm}^{-1}$. The weak peak at $1241 \mathrm{~cm}^{-1}$ that appear only in the IR spectrum of the free ligand, was assigned to the stretching modes of $\mathrm{C} 2-\mathrm{N} 3-\mathrm{C} 4$ and $\mathrm{C} 6=\mathrm{C} 5-\mathrm{C} 4$, while in the Raman spectra these vibrations appear also for the complex. The bands around $1015 \mathrm{~cm}^{-1}$, weak in IR and medium in Raman spectra, can be due to the symmetrical $\mathrm{C}=\mathrm{O}$ stretching mode, whereas bands around $930 \mathrm{~cm}^{-1}$ almost weak in IR and medium in Raman spectra, were attributed to the symmetrical $\mathrm{C}$ (ring)-C(carboxyl) bridge bond stretching mode. The uracilate ring bending vibration and the skeletal deformation bands of the free orotic acid, mainly in the $900-300 \mathrm{~cm}^{-1}$ wavenumber region, show considerable changes on complex formation (Figures 3 ) (Figure 4) (Table 1). These changes may be attributed to distorsion of the uracilate rings upon coordination.

The new bands at $440-470 \mathrm{~cm}^{-1}$ in the IR and Raman spectra, which appear only for the In(III) complex, can be due to the indiumoxygen interactions [35]. In the low wavenumbers region of the Raman spectrum of orotic acid (Figure 4), the medium strong band at 395 $\mathrm{cm}^{-1}$ is importantly shifted to the shorter wavenumbers in the Raman spectrum of the In(III) complex and became weaker. This one and the new neighbouring band at $345 \mathrm{~cm}^{-1}$ (in the Raman spectrum of the complex) can be due to the indium-oxygen vibration modes [44-48]. The metal affects the carboxylate anion as well as the ring structure. The ionic potential of the metal is the most important parameter responsible for the influence of the metal on the rest of the molecule [49-51]. The carboxylic acids interact with the metals as symmetric $[52,53]$, bidentate carboxylate anions and both oxygen atoms of the carboxylate are symmetrically bonded to the metal [54]. In this sense, we can observe in the Raman spectra of the In(III) complex a very weak peak at $306 \mathrm{~cm}^{-1}$, which can be due to the O-In-O vibration modes (Table 1) [48,55-57].

From our previous results regarding the newly synthesised lanthanide complexes and this work, it is clear that the nature of orotic acid makes its various anionic forms versatile ligands for use with a variety of metals and for a variety of objectives/advantages, including variable coordination modes. Thus, the ligand orotic acid has great potential as a generally useful polyfunctional ligand in metal coordination chemistry and it will prove attractive to a variety of coordination chemists.

On the basis of the detailed vibrational analysis the most probable structure of the obtained In(III) complex was suggested (Figure 5).

\section{Pharmacology}

Effects of $\mathrm{HOA}, \mathrm{NaOA}$ and InOA on isolated rat liver microsomes: One of the most suitable sub-cellular in vitro systems for investigation of drug metabolism is isolated microsomes.

Administered alone, HOA, NaOA and InOA, didn't reveal statistically significant toxic effects on isolated rat microsomes. The level of malondialdehyde (MDA), marker for lipid peroxidation, was not increased statistically significant from all compounds, compared to the control (non-treated microsomes) (Figure 6).

In conditions of non-enzyme-induced lipid peroxidation, only the complex InOA revealed statistically significant antioxidant activity, compared to toxic agent $-\mathrm{Fe}^{2+} / \mathrm{AA}$ (iron/ascorbate). $\mathrm{HOA}$ and $\mathrm{NaOA}$ didn't show antioxidant activity at this toxicity model (Figure 7).

Microsomes incubation with $\mathrm{Fe}^{2+} / \mathrm{AA}$, resulted in statistically significant increase of the amount of MDA with $191 \%$ vs control (nontreated microsomes). In non-enzyme-induced lipid peroxidation model, the pre-teratement only with the complex InOA, at concentration 100 $\mu \mathrm{M}$, significantly reduced lipid damage by $64 \%$, as compared to the

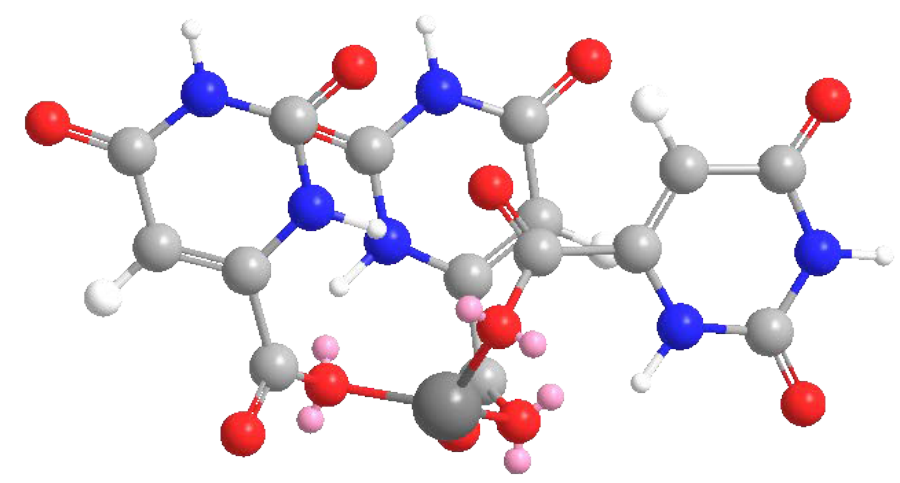

Figure 5. The suggested structure of In(III) complex of orotic acid 


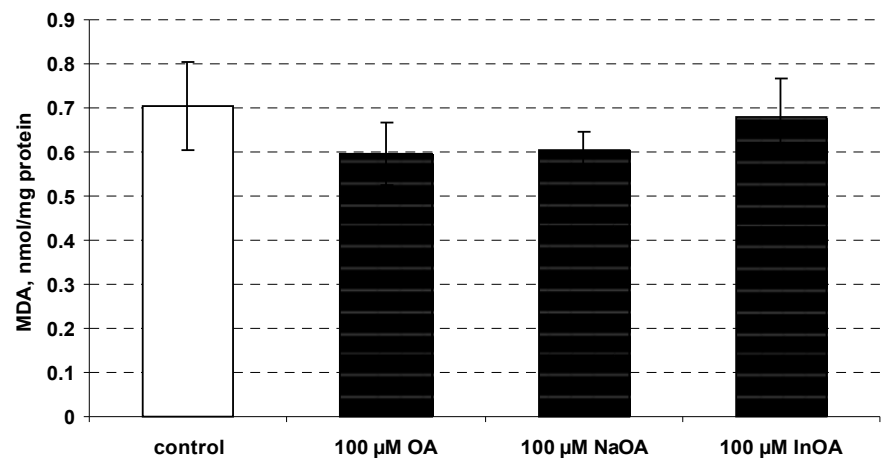

Figure 6. Effects of $\mathrm{HOA}, \mathrm{NaOA}$ and $\mathrm{InOA}$ (at concentration $100 \mu \mathrm{M}$ ), administered alone, on isolated rat microsomes

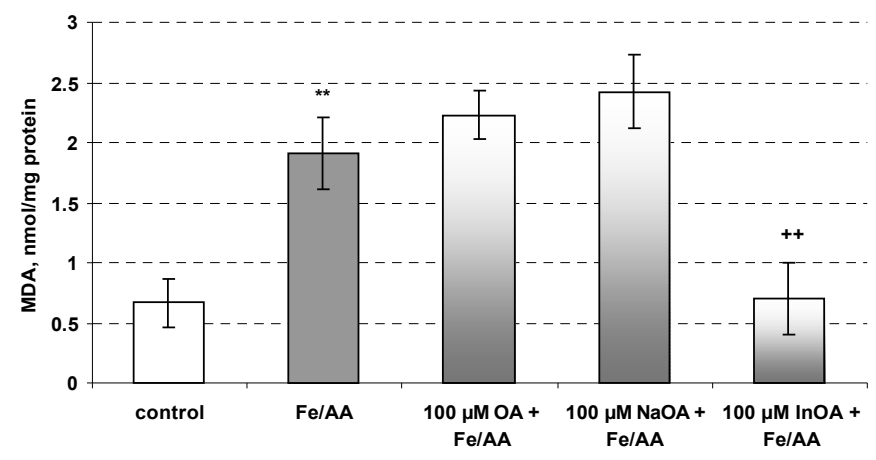

Figure 7. Effects of $\mathrm{HOA}, \mathrm{NaOA}$ and InOA (at concentration $100 \mu \mathrm{M}$ ), in non-enzymeinduced lipid peroxidation, on isolated rat microsomes

$* * \mathrm{P}<0.01$ vs control (non-treated microsomes)

$+\mathrm{P}<0.01$ vs toxic agent $\left(\mathrm{Fe}^{2+} / \mathrm{AA}\right)$

toxic agent $\left(\mathrm{Fe}^{2+} / \mathrm{AA}\right)$. $\mathrm{HOA}$ and $\mathrm{NaOA}$ didn't show antioxidant activity in this toxicity model (Figure 7).

The microsomal fraction, which is prepared by differential centrifugation, contents fragments from the endoplasmatic reticulum and preserve the enzyme activity, mostly cytochrome P450 enzymes. Microsomes are used as a model of lipid membrane in experiments, related to the process of lipid peroxidation [58]. Here, we show that only the complex InOA revealed statistically significant antioxidant effect in non-enzyme-induced lipid peroxidation in isolated microsomes. The effects of InOA might be due to the presence of metal ions.

\section{Conclusion}

The complex of indium(III) with orotic acid has been synthesized and characterized by elemental and vibrational (IR, Raman) analyses. The vibrational analysis performed for the studied species, orotic acid and its In(III) complex, helped to explain the vibrational behaviour of the ligand vibrational modes, sensitive to interaction with In(III). The most probable metal-ligand binding mode in the In(III) complex of orotic acid was elucidated. It is suggested that orotic acid binds through the oxygen atoms of the carboxylic groups from the ligands.

The results from the preliminary pharmacological investigations of orotic acid, sodium salt of orotic acid and In(III) complex demonstrate the antioxidant potential of the In(III) complex which is in line with our preceding papers concerning the activity of lanthanide coordination compounds with various biologically active ligands. The complex formation proved to be beneficial for the exerted efficacy of the In(III) complex vs. the corresponding ligand and its sodium salt. Thus, the newly synthesised In(III) complex necessitates further more detailed pharmacological evaluation.

\section{Acknowledgement}

The authors gratefully acknowledge the financial support from the Medical University-Sofia Grant Commission (Grant №78/2018).

\section{References}

1. Dodin G, Dubois JE (1980) Tautomerism of orotic acid dianion. effect of calcium and magnesium cations on the tautomeric constant and on tautomerization dynamics. $\mathrm{J} \mathrm{Am}$ Chem Soc 102: 3049-3056.

2. Arrizabalaga P, Castan P, Dahan F (1983) Coordination sites of 5-nitro-6-carboxyuracil UV study and x-ray structure determination of diammine(5-nitroorotato)copper(II) hydrate and hexaamminebis(5-nitroorotato)tricopper(II) pentahydrate. Inorg Chem 22: 2245-2252.

3. Arrizabalaga P, Castan P, Laurent JP (1984) Intramolecular influence of a carboxylic function on platinum blue synthesis, A systematic study of complexes originating from acid amides. J Am Chem Soc 106: 4814-4818.

4. Lea MA, Luke A, Assad A, Patel M, Reddy PA (1992) Inhibitory action of orotate 2-thioorotate and isoorotate on nucleotide metabolism and nucleic acid synthesis in hepatoma cells. Int J Biochem 24: 1453-1459. [Crossref]

5. Casas JS, Sordo J, Hiller W, Strahle J (1991) Reaction of dimethylhydroxythallium(III) with 2-thioorotic acid, Crystal structure of dimethyl(2-thioorotato)thallium(III) monohydrate. Inorg Chim Acta 181: 43-49.

6. Hueso-Ureña F, Moreno-Carretero MN, Salas-Peregrin JM, De Cienfuegos-Lopez GA (1995) Silver(I), palladium(II), platinum(II) and platinum (IV) complexes with isoorotate and 2-thioisoorotate ligands: synthesis, I.R. and N.M.R. spectra, thermal behaviour and antimicrobial activity. Trans Metal Chem 20: 262-269.

7. Hueso-Ureña F, Moreno-Carretero MN, Romero-Molina MA, Salas-Peregrin JM, Sanchez-Sanchez MP (1993) Transition metal complexes with monodeprotonated isoorotic and 2-thioisoorotic acids: Crystal structure, spectral and magnetic study, and antimicrobial activity. J Inorg Biochem 51: 613-632.

8. Kumberger O, Riede J, Schmidbaur H (1993) Preparation and crystal structure of zinc bis[orotate(1-)] octahydrate. Zeits Naturforsch B 48: 961-964.

9. Bach I, Kumberger O, Schmidbaur H (1990) Orotate complexes. Synthesis and crysta structure of lithium orotate(I) monohydrate and magnesium bis[orotate(I)] octahydrate. Chem Berich 123: 2267-2271.

10. Kostova I, Trendafilova N, Momekov G (2005) Theoretical and spectroscopic evidence for coordination ability of 3,3'-benzylidenedi-4-hydroxycoumarin. New neodymium (III) complexes and its cytotoxic effect. J Inorg Biochem 99: 477-487.

11. Kostova I, Traykova M (2006) Cerium(III) and neodymium(III) complexes as scavengers of X/XO-derived superoxide radical. Med Chem 2: 463-470. [Crossref]

12. Kostova I, Peica N, Kiefer W (2006) Theoretical and spectroscopic studies of lanthanum (III) complex of 5-aminoorotic acid. Chem Phys 327: 494-505.

13. Kostova I, Momekov G (2008) Synthesis, spectral and pharmacological studies on lanthanide(III) complexes of 3, 5-pyrazoledicarboxylic acid. J Coord Chem 61: 3776 3792 .

14. Kostova I, Stefanova T (2009) Synthesis, characterization and cytotoxic/cytostatic activity of Sm(III) and Gd(III) complexes. J Coord Chem 62: 3187-3197.

15. Kostova I, Valcheva-Traykova M (2015) New samarium(III) complex of 5-aminoorotic acid with antioxidant activity. Appl Organomet Chem 29: 815-824.

16. Kostova I, Peica N, Kiefer W (2007) Theoretical and spectroscopic studies of 5-aminoorotic acid and its new lanthanide (III) complexes. J Raman Spectrosc 38: 205216.

17. Collery P, Keppler B, Madoulet C, Desoize B (2002) Gallium in cancer treatment. Crit Rev Oncol Hematol 42: 283-296. [Crossref]

18. Mohammadi K, Thompson KH, Patrick BO, Storr T, Martins C (2005) Synthesis and characterization of dual function vanadyl, gallium and indium curcumin complexes for medicinal applications. J Inorg Biochem 99: 2217-2225.

19. Frisch MJ, Trucks GW, Schlegel HB, Scuseria GE, Robb MA et al. (2003) Gaussian 03, Revision B, 04, Gaussian Inc, Pittsburgh PA, 12, 2003.

20. Becke AD (1993) Density-functional thermochemistry. III. The role of exact exchange. J Chem Phys 98: 5648-5652. 
21. Perdew JP (1991) Electronic structure of solids; Eds. P. Ziesche, H. Eschrig; Akademie Verlag, Berlin, 11, 1991.

22. Perdew JP, Wang Y (1992) Pair-distribution function and its coupling-constant average for the spin-polarized electron gas. Phys Rev B Condens Matter 46: 12947-12954. [Crossref]

23. Becke AD (1992) Density-functional thermochemistry. II. The effect of the PerdewWang generalized-gradient correlation correction. J Chem Phys 97: 9173-9177.

24. Gelfand LS, Iaconianni FJ, Pytlewski LL, Speca AN, Mikulski CM (1980) Nicotinic and isonicotinic acid n-oxide interactions with $3 \mathrm{~d}$ metal perchlorates. $J$ Inorg $\mathrm{Nucl}$ Chem 42: 377-385.

25. Lee C, Yang W, Parr RG (1988) Development of the Colle-Salvetti correlation-energy formula into a functional of the electron density. Phys Rev B Condens Matter 37: 785789. [Crossref]

26. Dunning TH, Hay PJ (1976) Modern Theoretical Chemistry; Eds. HF Schaefer; Plenum, New York, 3, 805, 1976

27. Deby C, Goutier R (1990) New perspectives on the biochemistry of superoxide anion and the efficiency of superoxide dismutases. Biochem Pharmacol 39: 399-405. [Crossref]

28. Lowry OH, Rosebrough NJ, Farr AL, Randall RJ (1951) Protein measurement with the Folin phenol reagent. $J$ Biol Chem 193: 265-275. [Crossref]

29. Kim HJ, Chun YJ, Park JD, Kim SI, Roh J K, et al. (1997) Protection of rat liver microsomes against carbon tetrachloride-induced lipid peroxidation by red ginseng saponin through cytochrome P450 inhibition. Planta Med 63: 415-418. [Crossref]

30. Oh KY, Roberts VH, Schabel MC, Grove KL, Woods M, Frians AE (2015) Gadolinium chelate contrast material in pregnancy: fetal biodistribution in the nonhuman primate. Radiology 276: 110-118. [Crossref]

31. Hernanz A, Billes F, Bratu I, Navarro R (2000) Vibrational analysis and spectra of orotic acid. Biopolymers 57: 187-198. [Crossref]

32. Icbudak H, Olmez H, Yesilel OZ, Arslan F, Naumov P (2003) Syntheses, characterization and crystal structures of novel amine adducts of metal saccharinates, orotates and salicylates. J Mol Struct 657: 255-270.

33. Papaefstathiou GS, Manessi S, Raptopoulou CP, Behrman EJ, Zafiropoulos TF (2004) The first metal complex of 5-hydroxyorotic acid: dimethylammonium bis (N, $\mathrm{N}$-dimethylformamide) bis (5-hydroxyorotato(-2)) gallate (III). Inorg Chem Comm 7: 69-72.

34. Kostova I, Peica N, Kiefer W (2007) Theoretical and spectroscopic studies of new lanthanum (III) complex of orotic acid. Vibr Spectrosc 44: 209-219.

35. Lencioni S, Pellerito A, Fiore T, Giuliani AM, Pellerito L (1999) Organometallic complexes with biological molecules. X: Dialkyltin (IV) and trialkyltin (IV) orotates: Spectroscopic and in vivo investigations. Appl Organomet Chem 13: 145-158.

36. Exner K, Fischer G, Bahr N, Beckmann E, Lugan M (2000) Proximate, synperiplanar bisdiazene skeletons: Syntheses, structures, homoconjugate reactivity and photochemistry. Eur J Org Chem 2000: 763-785.

37. Castaneda JP, Denisov GS, Kucherov SY, Schreiber VM, Shurukhina AV (2003) Infrared and ab initio studies of hydrogen bonding and proton transfer in the complexes formed by pyrazoles. $J$ Mol Struct 660: 25-40.

38. González-Sánchez F (1958) Infra-red spectra of the benzene carboxylic acids. Spectrochim Acta 12: 17-33.

39. Hadzi D, Sheppard N (1953) The infra-red absorption bands associated with the $\mathrm{COOH}$ and COOD groups in dimeric carboxylic acids. I. The region from 1500 to $500 \mathrm{~cm}^{-1}$. Proc Roy Soc Ser A 216: 247-266.
40. Lin-Vien D, Colthup NB, Fateley WG, Grasselli JG (1991) The Handbook of Infrared and Raman Characteristic Frequencies of Organic Molecules, Edited by Jovanovich HB, Academic Press Inc., San Diego 140, 1991.

41. Dolish FR, Fateley WG, Bentley FF (1974) Characteristic Raman Frequencies of Organic Compounds, John Wiley\&Sons Inc. 128, 1974.

42. Orza JM, Garci'a MV, Alkorta I, Elguero J (2000) Vibrational spectra of 3,5-dimethylpyrazole and deuterated derivatives. Spectrochim Acta A 56: 1469-1498. [Crossref]

43. Szabó A, Cešljevic VI, Kovács A (2001) Tautomerism, hydrogen bonding and vibrational properties of 4-acetyl-3(5)-amino-5(3)-methylpyrazole. Chem Phys 270: $67-78$.

44. Sourisseau C, Fouassier M, Mauricot R, Boucher F, Evain M (1997) Structure and bonding in cerium oxysulfide compounds. II Comparative lattice dynamics calculations on Ce2O2S and Ce2.O2.5S. J Raman Spectrosc 28: 973-978.

45. Lu Y, Deng G, Miao F, Li Z (2003) Metal ion interactions with sugars. The crystal structure and FT-IR study of the NdCl3-ribose complex. Carbohydr Res 338: 2913 2919. [Crossref]

46. Sohn JR, Chun EW, Pae YI (2003) Spectroscopic studies on ZrO2 modified with MoO3 and activity for acid catalysis. Bull Korean Chem Soc 24: 1785-1792.

47. Jayaraman A, Sharma SK, Wang SY, Shieh SR, Ming LC (1996) Pressure-induced phase transitions in $\mathrm{KDy}(\mathrm{MoO} 4) 2$ and $\mathrm{KY}(\mathrm{MoO} 4) 2$ : a high-pressure Raman study. $J$ Raman Spectrosc 27: 485-490.

48. Fielicke A, Meijer G, Von Helden G (2003) Infrared multiple photon dissociation spectroscopy of transition metal oxide cluster cations. Eur Phys $J$ 24: 69-72.

49. Lewandowski W, Dasiewicz B, Koczon P, Skierski J, Dobrosz-Teperek K (2002) Vibrational study of alkaline metal nicotinates, benzoates and salicylates. $J$ Mol Struct 604: 189-193.

50. Koczon P, Lewandowski W, Mazurek AP (1999) Vibrational (FT-IR and FT-Raman) and NMR studies on selected metal (Ca, Mn, $\mathrm{Zn}$ ) complexes with ortho-, meta-, and para-iodobenzoic acids. Vibr Spectrosc 20: 143-149.

51. Kakiuchi M, Abe T, Nakayama H (2001) D/H fractionation factor between water vapor and crystal water of copper chloride dihydrate: Statistical mechanical approach based on Raman spectra. Geochem J 35: 285-293.

52. Wang K, Li YS (1997) Silver doping of polycarbonate films for surface-enhanced Raman scattering. Vibr Spectrosc 14: 183-188.

53. Boerio FJ, Hong PP, Clark PJ, Okamoto Y (1990) Surface-enhanced Raman scattering from model acrylic adhesive systems. Langmuir 6: 721-727.

54. Kwon YJ, Dong HS, Sang JA, Myung SK, Kwan K (1994) Vibrational spectroscopic investigation of benzoic acid adsorbed on silver. J Phys Chem 98: 8481-8487.

55. Galdecka E, Galdecki Z, Huskowska E, Amirkhanov V, Legendziewicz J (1997) Crystal structure and optical properties of Ln(III) octahedral complexes with hexameth ylphosphortriamide;[Ln(HMPA)6](ClO4)3. J Alloys Comp 257: 182-190.

56. de Andrés A, Taboada S, Martínez JL, Salinas A, Hernández J, et al. (1993) Optical phonons in $\mathrm{R} 2 \mathrm{BaMO} 5$ oxides with $\mathrm{M}=\mathrm{Co}, \mathrm{Ni}, \mathrm{Cu}$, and $\mathrm{R}=\mathrm{a}$ rare earth. Phys Rev $B$ Condens Matter 47: 14898-14904. [Crossref]

57. Cho BO, Lao SX, Chang JP (2003) Origin and effect of impurity incorporation in plasma-enhanced $\mathrm{ZrO} 2$ deposition. J Appl Phys 93: 9345-9351.

58. Zaidi SI, Agarwal R, Eichler G, Rihter BD, Kenney ME (1993) Pharmacodynamic effects of new silicon phthalocyanines: In vitro studies utilizing rat hepatic microsomes and human erythrocyte ghosts as model membrane sources. Photochem Photobiol 58 : 204-210.

Copyright: (C2018 Kostova I. This is an open-access article distributed under the terms of the Creative Commons Attribution License, which permits unrestricted use, distribution, and reproduction in any medium, provided the original author and source are credited. 